\title{
Specificity and exclusiveness of human capital and corporate control in Chinese entrepreneurial firms
}

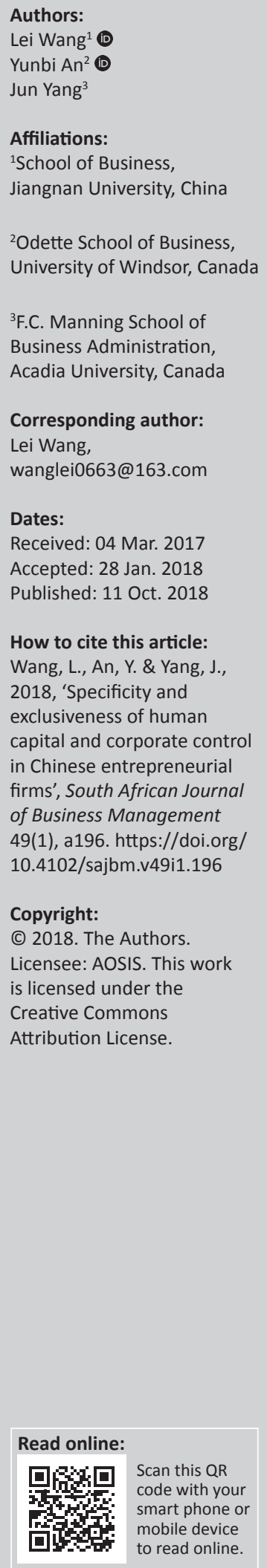

Background: Entrepreneur was the key factor of venture capital-backed star-ups, and control rights serve as an important incentive to attract entrepreneurs' human capital investment.

Objective: In this article, we investigate the ways in which the specificity and exclusiveness of entrepreneurs' human capital impact the allocation of residual control right (RCR) and specific control right (SCR) in entrepreneurial firms, based on the comprehensive effect of various control right benefits.

Methods: Using panel data for a mixed regression model, we test theoretical hypotheses with survey data collected from entrepreneurial firms in various industries in China.

Results: We find that when the venture capitalist's (VC) strategic benefits are less than the entrepreneur's private benefits, the VC's RCR is negatively related to the specificity of the entrepreneur's human capital and is positively related to the exclusiveness of the entrepreneur's human capital. The VC's SCR is positively related to the specificity and is negatively related to exclusiveness. When the VC's strategic benefits are greater than the entrepreneur's private benefits, the VC's RCR is positively related to the specificity of the entrepreneur's human capital and is negatively related to the exclusiveness. The VC's SCR is positively related to both the specificity and exclusiveness.

Conclusion: The impacts of specificity and exclusiveness of human capital are more significant for high-tech companies than for traditional companies. It is necessary for different types of VC-backed firms to implement classified governance over the control rights.

\section{Introduction}

Entrepreneurial firms are typically characterised as human capital-intensive enterprises, and thus, the entrepreneurs' human capital represents a primary source of the firms' sustainable competitive advantage and plays a crucial role in their innovative performance (Coff 1997; Hitt et al. 2001; Mumcu 2010). Human capital is distinct from physical capital and financial capital in two ways. Firstly, human capital is inalienable, and entrepreneurs can choose to leave the firms at their will (Hart \& Moore 1994). Secondly, human capital exhibits strong specificity and exclusiveness (Zhou 2002). The specificity of entrepreneurs' human capital refers to their firmspecific knowledge, skills, and abilities that are only applicable in a given firm (Coff 1997). Once an entrepreneur leaves the firm, the value of the firm-specific human capital is substantially reduced or completely lost (Williamson 1996). According to Becker (1962), firm-specific human capital is best understood as a shared investment because its value relies on the input of other parties. In contrast, the exclusiveness of human capital refers to its uniqueness and irreplaceability, which is often the basis for the creation and development of an enterprise. Exclusive human capital is directly linked to the innovativeness and scarcity, and the value of other sources in the firm is dependent upon it. This feature enables an entrepreneur to transfer to other firms without losing value in human capital. However, if an entrepreneur leaves the firm, the remaining resources of the firm would lose value, which may lead to reduced firm productivity or even dissolution (Yang \& Yang 2001), while the value of the entrepreneur's exclusive human capital remains unchanged (Alchain \& Woodard 1987).

Entrepreneurial firms are primarily financed by venture capital funds and thus are subject to the principal-agent problem. While entrepreneurs assume the risk of being stuck in firms because of their specific human capital, venture capitalists or venture capital companies (VCs) are concerned that the exclusiveness of entrepreneurs' human capital enables entrepreneurs to 'hold-up' the VCs by threatening to leave the firm (Hart \& Moore 1994). It is clear that the financial contracts between entrepreneurs and VCs (hereafter, VC contracts) should reflect the features of human capital and 
provide incentives to retain entrepreneurs' human capital (Gimmon \& Levie 2010; Patzelt 2010). A key challenge is to design VC contracts with optimal allocation of control rights between entrepreneurs and VCs.

This article explores the ways in which specificity and exclusiveness of entrepreneurs' human capital impact the allocation of residual control right (RCR) and specific control right (SCR) - the two types of contractual rights according to the incomplete contract theory (Grossman \& Hart 1986; Hart \& Moore 1990). Residual control right refers to the decision-making powers that are not clearly specified in VC contracts, the powers in contracts that parties may understand differently or the powers to deal with unexpected events without precedents. Specific control right refers to the control rights that are clearly specified in contracts, such as operation and management rights in enterprises (Hart \& Moore 1990). The enterprise control right is a complete set consisting of RCR and SCR, which complement each other. The VC and the entrepreneur in an entrepreneurial firm have to make a compromise when sharing control rights because the fate of the venture relies on their joint effort and effective cooperation. It is important to understand how their sharing of RCR and SCR is related to the entrepreneur's human capital.

There is a rich body of literature on the relationship between human capital and enterprise control rights. Focusing on the IT industry, Jørgensen, Kort and Dockner (2006) find that intellectual capital of the entrepreneur team affects control right sharing between the VC and management team. Bottazzi, Rin and Hellmann (2008) believe that motivated investors with human capital contribute strongly to the success of entrepreneurial firms, and the main means of motivation includes control right and cash flow right. Rajan (2012) argues that to have access to external financing, entrepreneurs must promise to reform and standardise the enterprise so that human capital, including entrepreneurs' own, becomes replaceable. Thus, external investors can gain control of the business. However, the irreplaceability of human capital grants its owner strong bargaining power, so the transfer of enterprise control rights may vary greatly in different situations. By opening up the 'black box' of the relationship between VCs and entrepreneurs, Turcan (2008) finds that VCs' investment objectives (strategic benefits of investment) determine the distribution of control right. Masulis and Nahata (2009) study Initial Public Offerings (IPOs) backed by venture capital and find that the strategic objectives of VCs influence the IPO enterprise control right distribution and share price; the complementary or competing relationship between VCs and entrepreneurs is also an important determining factor. From the perspective of strategic alliance, Wang et al. (2012) empirically study the value of enterprises backed by venture capital and find that VCs' strategic objectives and enterprise value determine the control right structure. Campbell and Frye (2009) and Ivanov et al. (2011) believe that the investment amount of VCs largely determines their control right. Lim and $\mathrm{Cu}$ (2012) base their analysis on social network and contract characteristics and notice that entrepreneurs' private benefits affect the cooperation and control right sharing between entrepreneurs and VCs. Drees, Mietzner and Schiereck (2013) find that firm value is an important indicator of control right structure, and the private benefits of new shareholders also matter for control rights.

The current literature has studied the control power distribution from the views of human capital and control right benefits. What is missing in the literature is how various control benefits can affect the mechanism through which the specificity and exclusiveness of the entrepreneur's human capital influence control rights in entrepreneurial firms.

The contributions of this study are threefold. Firstly, at the theoretical level, we disentangle the control right benefits of the entrepreneur and the VC and discuss how the interaction between private benefits and pecuniary benefits of the two parties shifts with their bargaining power and thus affects the sharing of RCR and SCR. Secondly, we explore simultaneously the effects of specificity and another key dimension of human capital, its exclusiveness, which is even more important in determining enterprise control rights (Yang \& Yang 2001). This extends previous studies that focus primarily on the impact of the specific human capital and specific investment on control rights. Thirdly, we test our hypotheses with data collected in a large-sample survey of Chinese entrepreneurial firms. Although China has the largest emerging economy in the world with entrepreneurial firms as a major driving force, academic research on Chinese entrepreneurial ventures, especially the control rights and their relationship with human capital, has been very rare. This study intends to contribute to filling this void in literature.

\section{Hypothesis development Types of control rights and composition of control benefits}

In their discussion of controlling shareholders' motives, Grossman and Hart (1988) decompose enterprise control benefits into two components: shared benefits and private benefits. Increased firm value caused by superior management or monitoring by new large shareholders is a shared benefit (Grossman \& Hart 1988; Shleifer \& Vishny 1986) because it is shared by all shareholders. Shared benefits of control usually take the form of explicit pecuniary benefits such as higher dividends, share price or firm valuation (Shleifer \& Vishny 1997; Zhou \& Gao 2012). On the other hand, private benefits of control rights are solely possessed by the owner of such rights. These benefits can be pecuniary such as high compensation and a large spending account, benefits from using corporate assets for personal purposes or even income resulting from insider information. They can also be nonpecuniary, such as psychological satisfaction from directing other people, or other perks and on-the-job consumption (Atanasov 2005; Dyke \& Zingales 2004). In entrepreneurial firms, both the VC and the entrepreneur possess private benefits from control rights, which are generally referred to 
as strategic benefits of the $\mathrm{VC}$ and private benefits of the entrepreneur (Barclay \& Holderness 1989; Schmidt 2003).

In modern corporate governance, shareholders generally enjoy the benefits of RCR, management enjoys the benefits of SCR and creditors receive the benefits of contingent control right (Liu \& Sun 2005). Entrepreneurial enterprises have different governance characteristics compared to mature enterprises. The entrepreneur, as the founder of the venture, is a major shareholder as well as the manager. The VC enjoys the rights of shareholders and often appoints some managers to the enterprise. In other words, the entrepreneur and the VC share RCR and SCR in the enterprise. The objective of this study is to explore how the sharing of control rights is related to the characteristics of the entrepreneur's human capital. We assume that shared benefits to the entrepreneur and the VC arising from RCR are pecuniary benefits of the control right, while the private benefits arising from SCR are non-pecuniary benefits (Wang 2014).

\section{Exclusiveness of human capital and control rights}

The exclusiveness of human capital implies that, once the owner of such human capital withdraws from the enterprise, the productivity of the firm would deteriorate quickly and the company may even dissolve. This possibility is especially evident in early stages of new enterprises - when the entrepreneur with highly exclusive and innovative technology leave the company, the company may have to be closed. Such a feature explains the strong bargaining position of the entrepreneur and the weak position of the VC.

\section{Impact of exclusiveness on control rights when entrepreneur's private benefits outweigh venture capital companies' strategic benefits}

Because the entrepreneur's private benefits are relatively large and the VC's strategic benefits are relatively small, the entrepreneur values more the SCR for private benefits and the VC places more value on the RCR for pecuniary benefits. As the entrepreneur's human capital becomes more exclusive, he would gain stronger bargaining power and request more SCR. To compromise and maintain the VC's financial capital and other inputs, the entrepreneur would be willing to transfer some RCR to the VC with pecuniary benefits. Thus, we have the following hypothesis:

Hypothesis 1: When the entrepreneur's private benefits are greater than the VC's strategic benefits, the VC's RCR is positively related to the exclusiveness of the entrepreneur's human capital and SCR is negatively related to exclusiveness.

\section{Impact of exclusiveness on control rights when venture capital companies' strategic benefits outweigh entrepreneur's private benefits}

In this situation, the VC places more value on the SCR that can bring more strategic benefits and the entrepreneur values more on RCR for pecuniary benefits. As the exclusiveness of the entrepreneur's human capital increases, the entrepreneur gains more bargaining power over the VC. With an emphasis on pecuniary benefits, the entrepreneur demands more RCR from the VC and is willing to transfer some SCR to the VC to maintain the collaborative relationship, compensating the VC with strategic benefits. Thus, we have the following hypothesis:

Hypothesis 2: When the VC's strategic benefits are greater than the entrepreneur's private benefits, the VC's RCR is negatively related to the exclusiveness of the entrepreneur's human capital, and the VC's SCR is positively related to the exclusiveness.

\section{Specificity of human capital and control rights}

Intuitively, specificity measures the degree to which the entrepreneur relies on other parts of the enterprise including the VC, and exclusiveness measures the degree to which the enterprise relies on the entrepreneur. Specificity and exclusiveness may transform into each other as the business develops. When the entrepreneur's exclusive human capital becomes more firm-specific, he is somewhat 'locked' in the firm. On the other hand, the entrepreneur's specific human capital can further develop so that he can gain stronger bargaining power in the firm, that is, his human capital can become somewhat exclusive. In all enterprises, the entrepreneur and the VC rely on each other to different degrees, and specificity and exclusiveness should be understood in relative terms. Because specificity and exclusiveness have a reciprocal relationship, their effects on RCR and SCR should be just opposite to each other.

Hypothesis 3: the VC's RCR and SCR are related to the specificity of the entrepreneur's human capital in the opposite ways as they are related to its exclusiveness.

\section{Specificity and exclusiveness of human capital and control rights in high-tech enterprises}

Compared to traditional enterprises, high-tech enterprises especially value human capital and intangible assets. Given that financial capital and physical capital are relatively less important in high-tech enterprises, the owner of exclusive human capital is capable of establishing a new firm to compete with existing firms. The particular importance of human capital in high-tech enterprises increases the potential threat to the interest of non-human capital, so it is important to constrain the behaviours of the entrepreneur. On the other hand, significantly increased bargaining power enables the owners of exclusive human capital to seek greater control in enterprises. We propose the following hypothesis:

Hypothesis 4: The impacts of specificity and exclusiveness of the entrepreneur's human capital on control rights are more pronounced for high-tech enterprises than for traditional companies.

\section{Research methodology Measuring key variables}

\section{Dependent variables}

Residual control rights: According to contemporary corporate governance theories, RCR is generally deemed equivalent to the control of the enterprise's board of directors. Entrepreneurs and management exercise RCR through board control 
(Wang 2014; Wang \& Dang 2008), and VCs also exercise RCR through board of directors and supervisors to monitor and control the behaviours of entrepreneurs. Following Aghion and Tirole (1997), Tirole (2001), Wang (2014) and Wang and Dang (2008), this study uses the arithmetic average of the percentages of board members, executive directors and supervising committee members that are occupied by VCs as the measure of $\mathrm{VCs}^{\prime} \mathrm{RCR}$.

Specific control rights: Lerner and Merges (1998) propose 10 measures on corporate control rights from three dimensions including key management decisions, enterprise scale decisions and corporate governance decisions. Among these proposed measures, management recruitment, top management control and board seat distribution are considered as board power in RCR (Wang 2014). The survey for this study collect data on seven measures regarding the SCR of VCs and entrepreneurs, including daily operations, mid-level manager recruiting and promotion, patent licensing, $R \& D$ project decisions, $R \& D$ investment amount decisions, new product development and capital project decisions. Following the calculation method of relative control in Liu and Ma (2004) and Wang (2014), we calculate the percentage of the VC's SCR in the total SCR of the VC and the entrepreneur as the measure of the VC's SCR in an entrepreneurial firm.

\section{Independent variables}

Residual claim: Residual claim is the claim on the revenue that remains after subtracting contractual payments. In Grossman and Hart (1986) and Hart and Moore (1990), measures on the residual claim include shares, deferred shares and options. Following Wang (2014) and Wang and Dang (2008), this study measures residual claims in entrepreneurial firms using the share ownership percentage of the VC and the entrepreneur.

Specificity of entrepreneur's human capital: The human capital uniqueness measures developed by Lepak and Snell (2002) have eight items, including 'not widely available in the labour market', 'would be very difficult to replace', 'not available to our competitors', 'widely considered the best in our industry', 'unique to our organisation', 'difficult for our competitors to imitate or duplicate', 'customised to our particular needs' and 'distinguish us from our competition'. Medina, Cabrales and Cabrera (2011) use these uniqueness measures in their study to evaluate innovative performance of human capital and social capital. This study adopts the eight measures as above on the specificity of entrepreneurs' human capital.

Exclusiveness of entrepreneur's human capital: The owner of exclusive human capital can exert certain control over the owners of non-human capital and has strong bargaining power in negotiations regarding enterprise ownerships. The monopoly power of human capital owners can undermine the completeness of contracts, thus granting certain control to human capital owners (Yang \& Zhou 1997).

Following Yang and Yang (2001), this study integrates the measures on the irreplaceability of human capital in Hatch and Dyer (2004), Jardon and Martos (2012) and Ruzzier et al. (2007) and adopts the following four considerations when measuring exclusiveness of human capital: (1) the ability to identify and achieve profitable market opportunities, (2) possession of some key technology with perspective of large commercial profit such as the ownership of important patents, (3) possession of a large amount of financial capital in an environment where such capital is scarce and (4) possession of special social capital that can produce significant commercial opportunities.

Industry character: Boxall and Purcell (2003) and Datta, Guthrie and Wright (2005) believe that reliance on human capital is much stronger in high-tech enterprises than in traditional enterprises. In this study, we employ a dummy variable for this separation, with industry character equal to one for high-tech enterprises and zero for traditional enterprises.

\section{Classification variables}

Non-pecuniary private benefits of entrepreneurs: Nonpecuniary private benefits of control refer to the social status and reputation that are associated with the control of an enterprise. The composition of private benefits arising from control is complex, including pecuniary income or nonpecuniary benefits via tunnelling and reputation gain, which is important to enterprise founders and family businesses (Helwege \& Packer 2009). Schmidt (2003) points out that private benefits of control can be significant even when compared to pecuniary benefits. For example, managers with academic backgrounds may pay more attention to the technological value of a project rather than the commercial value. Environmentally conscious managers or advocates of local economic developments may not always maximise enterprise value when making decisions. Based on these analyses, this study adopts four measures on entrepreneurs' non-pecuniary private benefits, including social status, on-the-job consumption, professional reputation and peer recognition (Wang 2014).

Non-pecuniary strategic benefits of venture capital companies: According to a survey on global corporate venture capital projects by Ernst and Young (2002), 67\% of corporations invest in entrepreneurial firms for strategic objectives. Ranked from highest to lowest, the strategic objectives include windows on technology developments, leveraging internal technological developments, importing or enhancing innovation with existing business units, corporate diversification and tapping into foreign markets. The strategic objectives of entrepreneurial investments should be closely connected to commercial activities of entrepreneurial firms, core competence, market strategy, development potential, competitive advantage, resource utilisation and industry functions (Gaba \& Bhattachary 2012). With reference to the measures on VCs' strategic benefits as developed in Wang (2014) and Weber and Weber (2005), this study adopts seven measures on VCs' non-pecuniary strategic benefits, including windows on technology developments, 
utilisation efficiency of technological platforms, support in the industrial chain, new market development, corporate diversification, economies of scale and economies of scope. Table 1 summarises the measures on the specificity and exclusiveness of entrepreneurs' human capital, non-pecuniary private benefits and strategic benefits.

\section{Control variables}

In this study, we control several variables at the enterprise level to separate their influence from the effect of the entrepreneur's human capital. Kaplan and Stromberg (2004) document that investment stage, firm size, industry and investment amount all affect the control right distribution. Zhang, Jia and Wan (2009) study control right sharing and operation efficiency in public-private joint enterprises in China and find that firm size and the nature of firms negatively affect VCs' control power, while the investment stage, industry and investment amount all positively affect VCs' control power. Following the literature, this study includes four control variables at the enterprise level as discussed subsequently.

Firm size: Firms are categorised into three groups based on the number of employees: small firms (less than 200 employees), medium firms (200-1000) and large firms (more than 1000). Large firms tend to have more resources, greater

TABLE 1: Summary of measures of key variables.

\begin{tabular}{|c|c|c|}
\hline Variables & Measures & Sources of reference \\
\hline $\begin{array}{l}\text { Specificity of } \\
\text { human capital }\end{array}$ & $\begin{array}{l}\text { 1. Not widely available in the labour } \\
\text { market } \\
\text { 2. Would be very difficult to replace } \\
\text { 3. Not available to our competitors } \\
\text { 4. Widely considered the best in our } \\
\text { industry } \\
\text { 5. Unique to our organisation } \\
\text { 6. Difficult for our competitors to imitate } \\
\text { or duplicate } \\
\text { 7. Customised to our particular needs } \\
\text { 8. Distinguish us from our competition }\end{array}$ & $\begin{array}{l}\text { Frank and Obloj (2014); } \\
\text { Lepak and Snell (2002); } \\
\text { Medina et al. (2011); } \\
\text { Vos and Dries (2013) }\end{array}$ \\
\hline $\begin{array}{l}\text { Exclusiveness } \\
\text { of human } \\
\text { capital }\end{array}$ & $\begin{array}{l}\text { 1. Ability to identify and achieve } \\
\text { profitable market opportunities } \\
\text { 2. Possession of some key technology with } \\
\text { perspective of large commercial profit } \\
\text { 3. Possession of a large amount of } \\
\text { currency capital in an environment } \\
\text { where such capital is scarce } \\
\text { 4. Possession of special social capital that } \\
\text { can produce significant commercial } \\
\text { opportunities }\end{array}$ & $\begin{array}{l}\text { Hatch and Dyer (2004); } \\
\text { Jardon and Martos } \\
\text { (2012); Ruzzier et al. } \\
\text { (2007) }\end{array}$ \\
\hline $\begin{array}{l}\text { Entrepreneurs' } \\
\text { private } \\
\text { benefits }\end{array}$ & $\begin{array}{l}\text { 1. Social status } \\
\text { 2. On-the-job consumption } \\
\text { 3. Professional reputation } \\
\text { 4. Peer recognition }\end{array}$ & $\begin{array}{l}\text { Helwege and Packer } \\
\text { (2009); Schmidt (2003); } \\
\text { Shleifer and Vishny } \\
\text { (1986); Wang (2014) }\end{array}$ \\
\hline $\begin{array}{l}\text { VCs' strategic } \\
\text { benefits }\end{array}$ & $\begin{array}{l}\text { 1. Windows on technology developments } \\
\text { 2. Utilisation efficiency of technological } \\
\text { platforms } \\
\text { 3. Support in the industrial chain } \\
\text { 4. New market development } \\
\text { 5. Corporate diversification } \\
\text { 6. Economies of scale } \\
\text { 7. Economies of scope }\end{array}$ & $\begin{array}{l}\text { Ernst and Young } \\
(2002) ; \text { Gaba and } \\
\text { Bhattachary (2012); } \\
\text { Wang (2014); Weber } \\
\text { and Weber (2005) }\end{array}$ \\
\hline
\end{tabular}

$\mathrm{VC}$, venture capital company.

Note: This table presents the measures of specificity of human capital, exclusiveness of human capital, entrepreneurs' private benefits, and VCs' strategic benefits in entrepreneurial firms. ability, as well as sufficient size for internally generated investment. Firm size is often used as a proxy for an enterprise's resources and ability. This study uses an ordinal variable size to measure firm size. Size is equal to 1 for small firms, 2 for medium and 3 for large firms.

Industry: This study adopts the 12 categorisations as in Listed Companies Industry Classification Guidelines of China and assigns the variable Industry a value from 1 to 12 for each industry.

Stage: Because it is difficult to collect time series data on the same entrepreneurial firms, this study collects a cross-section sample of entrepreneurial firms and uses the ordinal variable Stage to represent their stages: 1 for start-up, 2 for growth, 3 for maturity and 4 for others.

Investment: The variable Investment is measured by the actual amount invested by the VC (in RMB10 000).

\section{Survey design and sample selection}

This study employs survey and interview methodologies. In this section, we discuss the design of the survey and test its applicability.

\section{Survey method}

Because there is no public database on entrepreneurial firms in China, we collect the required data through field studies and surveys. In a preliminary round, a small number of field studies and interviews are conducted to gain insight into the current status of control rights in Chinese entrepreneurial firms. Then, a large-sample survey is conducted with mid- to high-level managers in VC companies to collect detailed information for the empirical analyses.

The design of the formal survey follows the issue-oriented principle and is based on the hypotheses to be tested. The questionnaire adopts the popular Likert scale (Dawes 2008; Likert 1932) with the following choices: 1 - completely insignificant (or completely unimportant), 2 - insignificant (or unimportant), 3 - neither significant nor insignificant, 4 significant (or important) and 5 - very significant (or very important). The degree of conformity with the question increases as the number increases.

\section{Large-sample survey}

This study focuses primarily on high-tech enterprises financed by VC companies, which are also the research subject of most existing literature. In recent years, VC companies in China have supported not only high-tech enterprises such as Internet of Things and new energy sources but also traditional enterprises such as manufacturing and financial businesses, chain restaurants, and education and training institutions. These traditional types of enterprises are also included in our survey so that the results can be compared to those of hightech enterprises. 
The survey sample includes regions with different levels of economic and market development, and such regional balance can ensure the generality of analytical results. This project selects representative cities from three regions: east, central and west China. In the east region, we selected Jinan, Shenzhen, Nanjing and Wuxi; in the central region, we selected Hefei; and in the west, we selected Xi'an and Wuzhou, where entrepreneurial investment has developed fairly quickly in recent years.

Most existing literature on corporate governance targets only top managers in their surveys. However, in our field studies, we realise that besides top-level managers, the midlevel managers, such as investment managers and project managers in VC firms, are also appropriate survey subjects. These managers maintain direct contact with entrepreneurial firms and thus are quite familiar with entrepreneurs and their firms. For this reason, the survey subjects include topand mid-level managers and investment decision committee members.

The survey in this project was conducted in two stages. The first stage was in the period of July to September 2009. Survey questionnaires were distributed via local networks (such as local entrepreneur associations or municipal government branches) in the target regions. In total, 450 copies of surveys were distributed, and 205 copies were later collected, with an overall response rate of $45.56 \%$. Among the returned surveys, 98 were invalid for various reasons including incomplete information, bankruptcy of entrepreneurial firms or disqualification of the respondents. Therefore, 107 valid completed surveys were received, with an effective response rate of $23.78 \%$. The sample size is sufficient for our statistical analysis. The second stage of the survey was conducted in the period from July to December 2011, which was meant to follow up with the 107 respondents in the valid sample from the previous survey. The second round of the survey revealed that among the 107 respondents, VCs exited successfully from 12 entrepreneurial firms, 9 firms were bankrupt, 15 firms received the secondor third-round investment from VCs and the remaining 71 were still working with the VC companies. The two rounds of survey yielded a valid sample size of 193, including 121 in strategic emerging or high-tech industries and 72 in traditional industries.

\section{Reliability and validity checks}

Prior to the empirical analysis, reliability and validity checks are conducted to ensure the quality of the data. Cronbach $\alpha$ is the most popular measure of reliability assessment. It has a value between zero and one, and the bigger the value, the higher the reliability. Generally speaking, Cronbach $\alpha$ on the measures of the same subject should be above 0.7. Table 2 reports the Cronbach $\alpha$ on the measures adopted in the study, which shows good reliability.
TABLE 2: Reliability and validity checks of survey data.

\begin{tabular}{|c|c|c|c|}
\hline Measure & $\begin{array}{c}\alpha \\
\text { coefficient }\end{array}$ & $\begin{array}{l}\text { Factor } \\
\text { load }\end{array}$ & $\begin{array}{l}\% \text { of variance } \\
\text { explained }\end{array}$ \\
\hline Specificity of entrepreneur's human capital & 0.713 & - & 62.56 \\
\hline 1. Not widely available in the labour market & - & 0.719 & - \\
\hline 2. Would be very difficult to replace & - & 0.761 & - \\
\hline 3. Not available to our competitors & - & 0.856 & - \\
\hline 4. Widely considered the best in our industry & - & 0.849 & - \\
\hline 5. Unique to our organisation & - & 0.705 & - \\
\hline $\begin{array}{l}\text { 6. Difficult for our competitors to imitate } \\
\text { or duplicate }\end{array}$ & - & 0.639 & - \\
\hline 7. Customised to our particular needs & - & 0.830 & - \\
\hline 8. Distinguish us from our competition & - & 0.789 & - \\
\hline Exclusiveness of entrepreneur's human capital & 0.801 & - & 72.46 \\
\hline $\begin{array}{l}\text { 1. Ability to identify and achieve profitable } \\
\text { market opportunities }\end{array}$ & - & 0.819 & - \\
\hline $\begin{array}{l}\text { 2. Possession of some key technology with } \\
\text { perspective of large commercial profit }\end{array}$ & - & 0.799 & - \\
\hline $\begin{array}{l}\text { 3. Possession of a large amount of currency } \\
\text { capital in an environment where such } \\
\text { capital is scarce }\end{array}$ & - & 0.763 & - \\
\hline $\begin{array}{l}\text { 4. Possession of special social capital that } \\
\text { can produce significant commercial } \\
\text { opportunities }\end{array}$ & - & 0.685 & - \\
\hline Entrepreneur's private benefits & 0.799 & - & 64.51 \\
\hline 1. Social status & - & 0.796 & - \\
\hline 2. On-the-job consumption & - & 0.819 & - \\
\hline 3. Professional reputation & - & 0.802 & - \\
\hline 4. Peer recognition & - & 0.750 & - \\
\hline VC's strategic benefits & 0.808 & - & 72.69 \\
\hline 1. Windows on technology developments & - & 0.845 & - \\
\hline $\begin{array}{l}\text { 2. Utilisation efficiency of technological } \\
\text { platforms }\end{array}$ & - & 0.882 & - \\
\hline 3. Support in the industrial chain & - & 0.786 & - \\
\hline 4. New market development & - & 0.668 & - \\
\hline 5. Corporate diversification & - & 0.851 & - \\
\hline 6. Economies of scale & - & 0.767 & - \\
\hline 7. Economies of scope & - & 0.810 & - \\
\hline
\end{tabular}

VC, venture capital company.

Popular validity tests include convergent validity and discriminant validity (Tan \& Litschert 1994). In this article, we test convergent validity in three ways. Firstly, in the process of preliminary screening and unidimensional test, an exploratory factor analysis is conducted to ensure no cross load between factors. Secondly, the factor load is calculated for each measure, as reported in Table 2. All the factor loads are significant $(p<0.01)$ and are above 0.6, indicating good convergent validity. Thirdly, the cumulative variance contribution rate (CVCR) is calculated for each factor. Its value is between zero and one, and the higher the value, the better the coupling. The CVCR of each factor is reported in Table 2, with all above $60 \%$, suggesting fine convergent validity.

The discriminant validity is tested with two methods. Firstly, for any two factors, we calculate the change in $\chi^{2}$ between two scenarios: when their correlation is one and when their correlation is free. Tests show that the change in $\chi^{2}$ is significant. Secondly, we calculate the $95 \%$ confident interval for the correlation coefficient between any two factors and notice that the interval does not include 1.0. These tests show that factors display satisfactory discriminant validity. 


\section{Empirical analyses Regression models}

To test our hypotheses, we consider the following two models:

$$
\begin{aligned}
R C R_{i t}= & a_{0}+a_{1} \text { Size }_{i t}+a_{2} \text { Industry }_{i t}+a_{3} \text { Stage }_{i t}+ \\
& a_{4} \operatorname{Ln}\left(\text { Investment }_{i t}\right)+a_{5}{\text { ResidualClaim } 1_{i t}} \\
& a_{6} \text { ResidualClaim }_{i t}+a_{7} \text { Specificity }_{i t}+a_{8} \text { Specificity }_{i t}{ }^{2}+ \\
& a_{9} \text { Exclusiveness }_{i t}+a_{10} \text { Exclusiveness }_{i t}{ }^{2}+\varepsilon_{i t}
\end{aligned}
$$

$$
\begin{aligned}
\text { SCR }_{i t}= & b_{0}+b_{1} \text { Size }_{i t}+b_{2} \text { Industry }_{i t}+b_{3} \text { Stage }_{i t}+ \\
& b_{4} \operatorname{Ln}\left(\text { Investment }_{i t}\right)+b_{5} \text { IC }^{+}+b_{6} \text { Specificity }_{i t}+ \\
& b_{7} \text { Specificity }_{i t}{ }^{2}+b_{8} \text { Exclusiveness }_{i t}+ \\
& b_{9} \text { Exclusiveness }_{i t}{ }^{2}+\varepsilon_{i t}
\end{aligned}
$$

The notations in Equations (1) and (2) are largely selfexplanatory: $R C R_{i t}$ and $S C R_{i t}$ are the VC's RCR and SCR, respectively. Size ${ }_{i t}$ is firm size; Industry ${ }_{i t}$ is industry type; Stage $_{i t}$ is development stage; $\operatorname{Ln}\left(\right.$ Investment $\left._{i t}\right)$ is the logarithm of investment amount (to eliminate the impact of extreme values); $I C_{i t}$ is industry character. ResidualClaim $1_{i t}$ and ResidualClaim $2_{i t}$ are the residual claims of the $\mathrm{VC}$ and the entrepreneur, respectively, while Specificity ${ }_{i t}$ and Exclusiveness are the specificity and exclusiveness of the entrepreneur's human capital, respectively. To accommodate potential nonlinear relations, the squared terms of specificity and exclusiveness are also included in the models.

After the pre-screening and reliability and validity tests, we calculate the average of measures for each factor as its overall measure. The descriptive analysis is conducted for the variables in the regression models; the results are reported in Table 3. Also reported in Table 4 is the correlation matrix for the variables. Overall, the quality and distribution of the data are satisfactory for further analysis.

TABLE 3: Descriptive statistics.

\begin{tabular}{lccccc}
\hline Variable & Observations & Mean & SD & Min. & Max. \\
\hline RCR & 193 & 0.247 & 0.076 & 0.162 & 0.367 \\
SCR & 193 & 0.425 & 0.204 & 0.133 & 0.630 \\
ResidualClaim1 & 193 & 0.243 & 0.084 & 0.15 & 0.4 \\
ResidualClaim2 & 193 & 0.664 & 0.131 & 0.4 & 0.8 \\
Specificity & 193 & 3.684 & 0.463 & 1 & 5 \\
Exclusiveness & 193 & 3.857 & 1.019 & 1 & 5 \\
\hline
\end{tabular}

$\mathrm{RCR}$, residual control right; SCR, specific control right; SD, standard deviation.

\begin{tabular}{lcccccc} 
TABLE 4: Correlation matrix. \\
\hline Variable & RCR & SCR & $\begin{array}{c}\text { Residual } \\
\text { Claim1 }\end{array}$ & $\begin{array}{c}\text { Residual } \\
\text { Claim2 }\end{array}$ & Specificity Exclusiveness \\
\hline RCR & 1 & - & - & - & - & - \\
SCR & 0.089 & 1 & - & - & - & - \\
ResidualClaim1 & -0.262 & 0.518 & 1 & - & - & - \\
ResidualClaim2 & 0.265 & -0.405 & -0.229 & 1 & - & - \\
Specificity & -0.274 & $-0.561\left(^{*}\right)$ & $-0.488\left(^{*}\right)$ & -0.298 & 1 & - \\
Exclusiveness & 0.023 & $0.665\left(^{*}\right)$ & $0.445\left(^{*}\right)$ & 0.293 & $-0.518\left(^{*}\right)$ & 1 \\
\hline
\end{tabular}

$\mathrm{RCR}$, residual control right; $\mathrm{SCR}$, specific control right; VC, venture capital company. Note: This table reports the descriptive statistics of the explained and the explanatory variables in our models, as well as the correlation matrix of these variables. RCR and SCR are the VC'S RCR and SCR, respectively. ResidualClaim1 and ResidualClaim2 are the residual claims of the VC and the entrepreneur, respectively. Specificity and Exclusiveness are the specificity and exclusiveness of the entrepreneur's human capital, respectively. ${ }^{*}$ indicate that correlation is significant at the $1 \%$ level (2-tailed).

\section{Regression analysis of residual control right}

In view of our hypotheses, we separate the sample into two groups based on whether the VC's strategic benefits $\left(S B_{V C}\right)$ exceed the entrepreneur's private benefits $\left(P B_{e}\right)$. We then conduct an analysis on RCR in these two situations with the full sample, the high-tech enterprise sample and the traditional enterprise sample.

\section{Full sample analysis}

Table 5 reports the regression results on the RCR with the full sample in the two situations.

(1) Residual control right when entrepreneur's private benefits outweigh venture capital companies' strategic benefits

Model M1.1 only considers the effects of control variables. The estimated coefficient of investment is positive and significant, indicating that the higher the investment amount, the more RCR the VC has in the firm. Other variables are insignificant.

M1.2 adds to M1.1 residual claims of the VC and the entrepreneur as well as industry character as explanatory variables, which increase the explanatory power of the model (adjust- $R^{2}$ increases from 0.151 to 0.227 ). Venture capitalist's RCR is positively related to the industry character at the $10 \%$ level, which indicates that the VC tends to have more RCR in a high-tech enterprise. Venture capitalist's RCR is negatively related to his residual claim at the $1 \%$ level, while the residual claim of the entrepreneur is insignificant.

M1.3 adds to M1.2 the specificity and exclusiveness of entrepreneurs' human capital, as well as the squared terms of specificity and exclusiveness for potential nonlinear effects. The model's adjust- $R^{2}$ further increases to 0.433 . Among the control variables, the investment stage becomes more significant at the 5\% level, while the effects of the other control variables remain unchanged. Industry character is now positive and significant at the $5 \%$ level, and the effects of the VC's and the entrepreneur's residual claims have not changed. The effect of the specificity of entrepreneur's human capital is significantly negative (at 10\%), yet in a nonlinear fashion, and the effect of exclusiveness is highly positive (at 1\%) in a nonlinear fashion. This finding is consistent with our hypothesis that the VC's RCR is negatively related to the specificity of the entrepreneur's human capital and is positively related to the exclusiveness.

(2) Residual control right when venture capital companies' strategic benefits outweigh entrepreneur's private benefits

M1.4 is the baseline model of this situation that includes control variables only, and its result resembles that of M1.1. Adding residual claims and industry character as independent variables to M1.4 forms M1.5, which shows increased explanatory power (adjust- $R^{2}$ increases from 0.126 to 0.211 ). The investment amount is positively related to the VC's RCR (significant at 5\%), and industry character is positively 
TABLE 5: Regression analysis of residual control right in entrepreneurial firms.

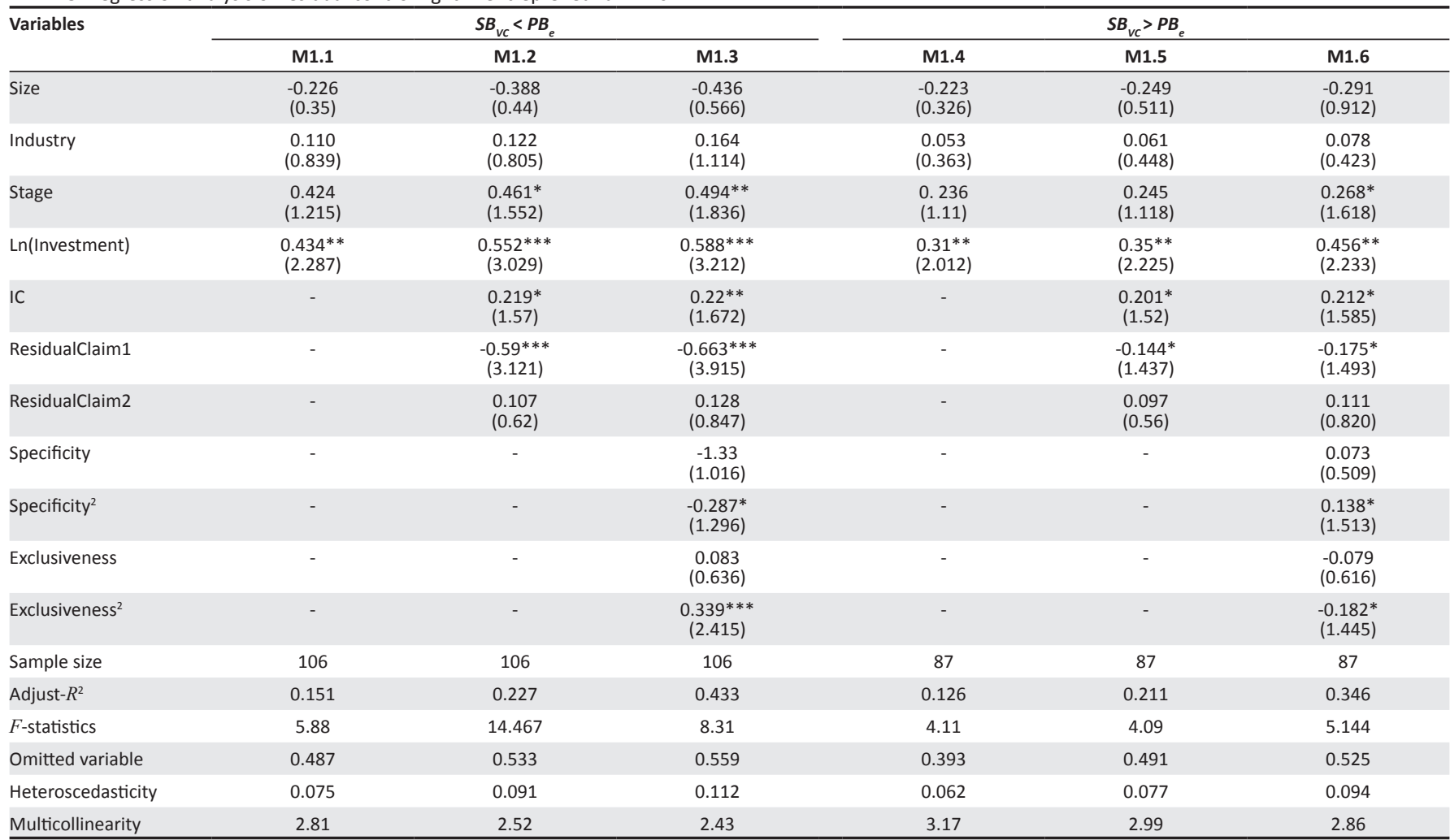

$\mathrm{RCR}$, residual control right; $\mathrm{VC}$, venture capital company.

Note: This table reports the estimation results for Model 1. $S B_{v c}$ stands for the VC's strategic benefits, and $P B$ stands for the entrepreneur's private benefits. The explained variable is $R C R$, the VC's RCR. The explanatory variables are as follows. Size is firm size; Industry is industry; Stage is development stage; Ln(Investment) is the logarithm of investment amount; IC is industry character. ResidualClaim 1 and ResidualClaim2 are the residual claims of the VC and the entrepreneur, respectively. Specificity and Exclusiveness are the specificity and exclusiveness of the entrepreneur's human capital, respectively. $t$-statistics are reported in the parentheses underneath the estimate. ${ }^{*}, * *$ and ${ }^{* * *}$ indicate significance at $10 \%, 5 \%$ and $1 \%$, respectively.

significant at $10 \%$. The effect of $\mathrm{VC}^{\prime}$ s residual claim is negatively significant at $10 \%$, while the entrepreneur's residual claim is insignificant.

As in M1.3, M1.6 adds the quadratic effects of the specificity and exclusiveness of the entrepreneur's human capital. The effects of control variables remain the same. The effect of specificity is significantly positive (at 10\%) although nonlinear, and the effect of exclusiveness is just the opposite (negative at $10 \%$ ). Such results show that the VC's RCR is positively related to the specificity of the entrepreneur's human capital and is negatively related to the exclusiveness.

To ensure the reliability of the results in Table 5, we conduct robustness checks to address potential concerns of omitted variables, heteroscedasticity and multicollinearity. The $p$-value of the omitted variable test is greater than 0.1 , of the heteroscedasticity test is greater than 0.05 , and the average variable inflation factor is less than five. These tests demonstrate that the models do not suffer from these concerns. The above results provide compelling evidence in favour of Hypotheses 1-3 regarding the impacts of specificity and exclusiveness of the entrepreneur's human capital on the VC's RCR.

\section{Regression analysis of enterprises in high-tech industries and traditional industries}

To test Hypothesis 4, we decompose the sample into two subsamples, one with observations for enterprises in hightech industries and the other for enterprises in traditional
TABLE 6: Regression analysis of residual control right in high-tech versus traditional enterprises.

\begin{tabular}{|c|c|c|c|c|}
\hline \multirow[t]{2}{*}{ Variables } & \multicolumn{2}{|c|}{ High-tech enterprises } & \multicolumn{2}{|c|}{ Traditional enterprises } \\
\hline & $S B_{v c}<P B_{e}$ & $S B_{v c}>P B_{e}$ & $S B_{v c}<P B_{e}$ & $S B_{v c}>P B_{e}$ \\
\hline Size & $\begin{array}{c}-0.266 \\
(1.012)\end{array}$ & $\begin{array}{c}-0.291 \\
(1.003)\end{array}$ & $\begin{array}{c}-0.193^{*} \\
(1.379)\end{array}$ & $\begin{array}{c}-0.197 * \\
(1.352)\end{array}$ \\
\hline Industry & $\begin{array}{l}0.202 * \\
(1.344)\end{array}$ & $\begin{array}{l}0.206^{*} \\
(1.399)\end{array}$ & $\begin{array}{c}0.155 \\
(1.195)\end{array}$ & $\begin{array}{l}0.157 * \\
(1.492)\end{array}$ \\
\hline Stage & $\begin{array}{c}0.407^{* *} \\
(1.961)\end{array}$ & $\begin{array}{c}0.289 * * \\
(1.716)\end{array}$ & $\begin{array}{c}0.364 * * * \\
(2.429)\end{array}$ & $\begin{array}{c}0.305 * * \\
(2.151)\end{array}$ \\
\hline Ln(Investment) & $\begin{array}{c}0.592 * * * \\
(4.402)\end{array}$ & $\begin{array}{r}0.368 * * \\
(2.227)\end{array}$ & $\begin{array}{c}0.506 * * * \\
(3.286)\end{array}$ & $\begin{array}{c}0.479 * * * \\
(3.593)\end{array}$ \\
\hline ResidualClaim1 & $\begin{array}{c}-0.699 * * * \\
(2.787)\end{array}$ & $\begin{array}{c}-0.386 * * \\
(1.966)\end{array}$ & $\begin{array}{c}0.483 * * * \\
(3.699)\end{array}$ & $\begin{array}{c}0.569 * * * \\
(4.593)\end{array}$ \\
\hline ResidualClaim2 & $\begin{array}{c}0.15 \\
(1.116)\end{array}$ & $\begin{array}{c}0.118 \\
(0.762)\end{array}$ & $\begin{array}{c}0.104 \\
(0.969)\end{array}$ & $\begin{array}{c}0.114 \\
(1.066)\end{array}$ \\
\hline Specificity & $\begin{array}{l}-0.107 \\
(0.926)\end{array}$ & $\begin{array}{c}0.087 \\
(0.697)\end{array}$ & $\begin{array}{l}-0.123 \\
(0.903)\end{array}$ & $\begin{array}{c}0.135 \\
(0.994)\end{array}$ \\
\hline Speciality ${ }^{2}$ & $\begin{array}{c}-0.226 * * \\
(2.00)\end{array}$ & $\begin{array}{c}0.213 * * \\
(1.828)\end{array}$ & $\begin{array}{c}-0.209 * \\
(1.665)\end{array}$ & $\begin{array}{l}0.18^{*} \\
(1.487)\end{array}$ \\
\hline Exclusiveness & $\begin{array}{c}0.19 \\
(0.664)\end{array}$ & $\begin{array}{l}-0.307 \\
(0.486)\end{array}$ & $\begin{array}{c}0.152 \\
(0.446)\end{array}$ & $\begin{array}{l}-0.186 \\
(0.861)\end{array}$ \\
\hline Exclusiveness $^{2}$ & $\begin{array}{c}0.463 * * * \\
(3.465)\end{array}$ & $\begin{array}{c}-0.237 * * \\
(1.883)\end{array}$ & $\begin{array}{c}0.276 * * \\
(1.998)\end{array}$ & $\begin{array}{c}-0.233^{*} \\
(1.659)\end{array}$ \\
\hline Sample size & 69 & 52 & 37 & 35 \\
\hline Adjust- $R^{2}$ & 0.501 & 0.394 & 0.363 & 0.327 \\
\hline F-Statistics & 7.815 & 5.372 & 3.064 & 2.653 \\
\hline
\end{tabular}

$\mathrm{RCR}$, residual control right; $\mathrm{VC}$, venture capital company.

Note: This table reports the estimation results for Model 1 for high-tech versus traditional enterprises. $\mathrm{SB}_{\mathrm{vc}}$ stands for the $\mathrm{VC}^{\prime}$ 's strategic benefits, and $\mathrm{PB}_{\mathrm{e}}$ stands for the entrepreneur's private benefits. The explained variable is $R C R$, the $V C^{\prime} s$ sCR. The explanatory variables are as follows. Size is firm size; Industry is industry. Stage is explanatory variables are as follows. Size is firm size; Industry is industry, Stage is development stage, Ln(Investment) is the logarithm of character. ResidualClaim1 and ResidualClaim 2 are the residual claims of the $\mathrm{VC}$ and the extrepreneur, respectively. Specificity and Exclusiveness are the specificity and exclusiveness of the entrepreneur's human capital, respectively. $l$-statistics are reported in the parentheses underneath the estimate. $*, * *$ and $* * *$ indicate significance at $10 \%, 5 \%$ and $1 \%$, respectively. 
industries. The estimated results using the two subsamples are reported in Table 6.

(1) Residual control right when entrepreneur's private benefits outweigh venture capital companies' strategic benefits

Based on the results in Table 6, we find that the effects of control variables are similar with slightly different significant levels for both subsamples. The impact of the VC's residual claim (ownership percentage) is negative for high-tech enterprises but positive for traditional enterprises. This suggests that in traditional industries the VCs' RCR is largely in line (proportional) with their ownership, but in hightech enterprises the VCs tend to have less RCR relative to their ownership. This observation implies that in high-tech industries entrepreneurs have more representation in boards and supervising committees, which reflects the bigger role that entrepreneurs play.

The estimated coefficients on Specificity ${ }^{2}$ are significantly negative for both subsamples, indicating that the impact of the specificity of the entrepreneur's human capital is negative (nonlinear though) for both high-tech and traditional companies. On the other hand, the estimated coefficients on Exclusiveness $^{2}$ are significantly positive for both subsamples. Moreover, in terms of the size and significance of the estimated coefficients, the influences of these two factors are more pronounced for high-tech companies than for traditional companies.

(2) Residual control right when venture capital companies' strategic benefits outweigh entrepreneur's private benefits
In this scenario, the effects of control variables and residual claims are almost the same as they are in the previous scenario. The effect of the specificity of the entrepreneur's human capital is positive in both subsamples, while the effect of the exclusiveness is negative in both subsamples. The effects of specificity and exclusiveness are stronger for high-tech enterprises than for traditional enterprises, which are consistent with the predictions in Hypothesis 4 . Additionally, the exclusiveness seems to have a stronger general impact (judged by significance of coefficients) than the specificity on the VC's RCR.

\section{Regression analysis of specific control right}

Table 7 reports the regression results for Model 2 for the full sample, the high-tech subsample and the traditional company subsample.

\section{When entrepreneur's private benefits outweigh venture capital companies' strategic benefits}

In this case, among the control variables, firm size and industry are insignificant for all samples. Stage is marginally negative ( $10 \%$ level) in two samples, and investment amount is positively significant. The effect of specificity is strongly positive in a convex fashion for all three samples, while the effect of exclusiveness is linear and negative. These effects are generally stronger in the high-tech sample than in the traditional company sample, which supports Hypothesis 4.

\section{When venture capital companies' strategic benefits outweigh entrepreneur's private benefits}

In this case, compared to the results reported in the last subsection, the effects of all control variables are largely

TABLE 7: Regression analysis of SCR for different types of enterprises.

\begin{tabular}{|c|c|c|c|c|c|c|}
\hline \multirow[t]{2}{*}{ Variables } & \multicolumn{3}{|c|}{$S B_{v c}<P B_{e}$} & \multicolumn{3}{|c|}{$S B_{v c}>P B_{e}$} \\
\hline & Complete sample & High-tech sample & Traditional sample & Complete sample & High-tech sample & Traditional sample \\
\hline Size & $\begin{array}{c}0.202 \\
(0.469)\end{array}$ & $\begin{array}{c}0.321 \\
(0.195)\end{array}$ & $\begin{array}{c}0.124 \\
(0.878)\end{array}$ & $\begin{array}{c}0.218 \\
(0.367)\end{array}$ & $\begin{array}{c}0.324 \\
(0.358)\end{array}$ & $\begin{array}{c}0.136 \\
(0.963)\end{array}$ \\
\hline Industry & $\begin{array}{l}0.051 \\
(0.36)\end{array}$ & $\begin{array}{c}0.06 \\
(0.437)\end{array}$ & $\begin{array}{c}0.039 \\
(0.279)\end{array}$ & $\begin{array}{l}0.077 \\
(0.557)\end{array}$ & $\begin{array}{c}0.062 \\
(0.469)\end{array}$ & $\begin{array}{c}0.055 \\
(0.405)\end{array}$ \\
\hline Stage & $\begin{array}{c}-0.179 * \\
(1.36)\end{array}$ & $\begin{array}{c}-0.212^{*} \\
(1.646)\end{array}$ & $\begin{array}{l}-0.137 \\
(1.062)\end{array}$ & $\begin{array}{c}-0.217^{*} \\
(1.614)\end{array}$ & $\begin{array}{c}-0.256^{* *} \\
(1.872)\end{array}$ & $\begin{array}{l}-0.157 \\
(1.215)\end{array}$ \\
\hline Ln(Investment) & $\begin{array}{l}0.211^{*} \\
(1.526)\end{array}$ & $\begin{array}{c}0.257^{* *} \\
(1.866)\end{array}$ & $\begin{array}{l}0.197 * \\
(1.427)\end{array}$ & $\begin{array}{c}0.301^{* *} \\
(2.045)\end{array}$ & $\begin{array}{c}0.376 * * * \\
(2.76)\end{array}$ & $\begin{array}{c}0.255^{* *} \\
(1.803)\end{array}$ \\
\hline IC & $\begin{array}{c}0.337 * * * \\
(2.703)\end{array}$ & - & - & $\begin{array}{c}0.367 * * * \\
(2.951)\end{array}$ & - & - \\
\hline Specificity & $\begin{array}{c}0.131 \\
(0.969)\end{array}$ & $\begin{array}{c}0.148 \\
(1.147)\end{array}$ & $\begin{array}{c}0.141 \\
(1.056)\end{array}$ & $\begin{array}{c}0.343 * * * \\
(2.707)\end{array}$ & $\begin{array}{c}0.357 * * * \\
(2.752)\end{array}$ & $\begin{array}{c}0.332 * * \\
(2.421)\end{array}$ \\
\hline Specificity $^{2}$ & $\begin{array}{c}0.276^{* *} \\
(1.991)\end{array}$ & $\begin{array}{c}0.367 * * * \\
(2.984)\end{array}$ & $\begin{array}{c}0.366^{* * *} \\
(2.889)\end{array}$ & $\begin{array}{c}0.067 \\
(0.466)\end{array}$ & $\begin{array}{c}0.112 \\
(0.825)\end{array}$ & $\begin{array}{c}0.102 \\
(0.741)\end{array}$ \\
\hline Exclusiveness & $\begin{array}{c}-0.343^{* *} \\
(2.217)\end{array}$ & $\begin{array}{c}-0.431 * * * \\
(3.398)\end{array}$ & $\begin{array}{c}-0.317 * * \\
(2.034)\end{array}$ & $\begin{array}{c}0.044 \\
(0.321)\end{array}$ & $\begin{array}{c}0.048 \\
(0.361)\end{array}$ & $\begin{array}{c}0.039 \\
(0.293)\end{array}$ \\
\hline Sample size & 106 & 69 & 37 & 87 & 52 & 35 \\
\hline Adjust- $R^{2}$ & 0.386 & 0.479 & 0.462 & 0.371 & 0.433 & 0.419 \\
\hline$F$-Statistics & 8.374 & 9.00 & 4.873 & 6.641 & 5.87 & 4.957 \\
\hline Omitted variable & 0.466 & 0.557 & 0.408 & 0.438 & 0.544 & 0.4 \\
\hline Heteroscedasticity & 0.087 & 0.113 & 0.094 & 0.082 & 0.104 & 0.088 \\
\hline Multicollinearity & 2.797 & 2.716 & 3.035 & 2.763 & 2.71 & 2.973 \\
\hline
\end{tabular}

SCR, specific control right; VC, venture capital company.

Note: This table reports the estimation results for Model 2 for different types of enterprises. $\mathrm{SB}_{\mathrm{vc}}$ stands for the VC's strategic benefits, and PB stands for the entrepreneur's private benefits. The explained variable is SCR, the VC's SCR. The explanatory variables are as follows. Size is firm size; Industry is industry; Stage is development stage; Ln(Investment) is the logarithm of investment amount; IC is industry character. Specificity and Exclusiveness are the specificity and exclusiveness of the entrepreneur's human capital, respectively. $t$-statistics are reported in the parentheses underneath the estimate. ${ }^{*}, * *$ and ${ }^{* * *}$ indicate significance at $10 \%, 5 \%$ and $1 \%$, respectively. 
unchanged except that the investment amount becomes more significant, especially in the sample of high-tech enterprises. The industry character is highly positive, suggesting significant difference in SCR between high-tech and traditional enterprises. The effect of specificity is significantly positive for all three samples, which is inconsistent with the negative relationship as hypothesised. The impact of exclusiveness is strongly positive in a convex fashion in all cases. Similar to the case in which entrepreneur's private benefits outweigh VC's strategic benefits, these effects are generally stronger in the high-tech sample than in the traditional company sample. Collectively, the preceding results generally support (in three out of four cases) our hypotheses about the ways in which specificity and exclusiveness of the entrepreneur's human capital are related to the VC's SCR.

To ensure the reliability of the results, robustness checks are conducted for the regressions in Table 7. Testing results show no concern for omitted variables, heteroscedasticity or multicollinearity.

\section{Conclusions}

This article investigates the ways in which the specificity and exclusiveness of entrepreneurs' human capital affect the allocation of RCR and SCR in Chinese entrepreneurial firms. We find that the exclusiveness and specificity of the entrepreneur's human capital have dramatically different effects on control right allocations in enterprises invested by VC. More specifically, we find that when the entrepreneur's private benefits are greater than the $\mathrm{VC}^{\prime}$ s strategic benefits, the VC's RCR is negatively related to the specificity of the entrepreneur's human capital and is positively related to the exclusiveness of the entrepreneur's human capital. The VC's SCR is positively related to the specificity and is negatively related to the exclusiveness. When the entrepreneur's private benefits are less than the VC's strategic benefits, the VC's $\mathrm{RCR}$ is positively related to the specificity of the entrepreneur's human capital and is negatively related to the exclusiveness of the entrepreneur's human capital. The VC's SCR is positively related to the specificity and exclusiveness. Overall, our hypotheses are supported by empirical findings in seven out of the eight relations studied. In either situation, the impacts of specificity and exclusiveness of human capital are more significant for high-tech companies than for traditional companies. Finally, we discover that in hightech entrepreneurial firms the VC's RCR and residual claims have a complementary relationship, while in traditional entrepreneurial firms the VC's RCR and residual claims are positively correlated.

The findings in this study suggest that VCs and entrepreneurs value control rights differently because of variations in control right benefits in entrepreneurial firms. Venture capitalists and entrepreneurs also prioritise RCR and SCR differently at different stages of enterprise development. For those firms with more strategic benefits for VCs, entrepreneurs should be primarily motivated with RCRs, inducing entrepreneurs to transform their exclusive human capital to enterprise-specific human capital in order to improve the firms' competence in technology innovation and support. When $\mathrm{VCs}^{\prime}$ strategic benefits are less than entrepreneurs' private benefits, entrepreneurs should be granted more SCR in early development stages to encourage the transformation of exclusive human capital to enterprise-specific human capital. When entrepreneurs' private benefits are less than VCs' strategic benefits, entrepreneurs should be granted more RCR in early development stages to encourage their increasing input of specific human capital. In high-tech entrepreneurial firms, if VCs' strategic benefits are less than entrepreneurs' private benefits, the VCs should be encouraged to increase specific investment to inspire entrepreneurs. Specific investments from both parties can alleviate hold-up and free-ride problems so as to improve innovation efficiency and financial performance.

\section{Acknowledgements}

This research is sponsored by the Ministry of Education in China, Project of Humanities and Social Sciences (17YJAZH080) and Jiangsu Qing Lan Project (Su Teacher [2017]15).

\section{Competing interests}

The authors declare that they have no financial or personal relationships which may have inappropriately influenced them in writing this article.

\section{Authors' contributions}

L.W. was responsible for theory analysis, survey design, sample selection and empirical analyses. Y.A. and J.Y. were responsible for hypothesis development and research methodology.

\section{References}

Aghion, P. \& Tirole, J., 1997, 'Formal and real authority in organizations', Journal of Political Economy 105(1), 1-29. https://doi.org/10.1086/262063

Alchain, A. \& Woodard, S., 1987, 'Reflections on the theory of the firm', Journal of Institution and Theoretical Economics 143(1), 110-136.

Atanasov, V.A., 2005, 'How much value can blockholders tunnel? Evidence from the Bulgarian mass privatization auctions', Journal of Financial Economics 76(1), 191234. https://doi.org/10.1016/j.jfineco.2004.05.005

Barclay, M.J. \& Holderness, C.G., 1989, 'Private benefits from control of public corporations', Journal of Financial Economics 25(2), 371-395. https://doi. org/10.1016/0304-405X(89)90088-3

Becker, G.S., 1962, 'Investment in human capital: A theoretical analysis', Journal of Political Economy 70(5), 9-49. https://doi.org/10.1086/258724

Bottazzi, L., Rin, M.D. \& Hellmann, T., 2008, 'Who are the active investors? Evidence from venture capital', Journal of Financial Economics 89(3), 488-512. https://doi. org/10.1016/j.jfineco.2007.09.003

Boxall, P. \& Purcell, J., 2003, Strategy and human resource management, Palgrave Macmillan, New York.

Campbell, T.L. \& Frye, M.B., 2009, 'Venture capitalist monitoring: Evidence from governance structures', The Quarterly Review of Economics and Finance 49(2), 265-282. https://doi.org/10.1016/j.qref.2008.05.001

Coff, R.W., 1997, 'Human assets and management dilemmas: Coping with hazards on the road to resource-based theory', The Academy of Management Review 22(2), 374-402. https://doi.org/10.5465/amr.1997.9707154063

Datta, D.K., Guthrie, J.P. \& Wright, P.M., 2005, 'Human resource management and labor productivity: Does industry matter?', Academy of Management Journal 48(1), 135-145. https://doi.org/10.5465/amj.2005.15993158 
Dawes, J., 2008, 'Do data characteristics change according to the number of scale points used? An experiment using 5-point, 7-point and 10-point scales',

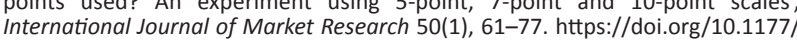
International Journal of
147078530805000106

Drees, F., Mietzner, M. \& Schiereck, D., 2013, 'Effects of corporate equity ownership on firm value', Review of Managerial Science 7(3), 277-308. https://doi. org/10.1007/s11846-012-0080-2

Dyke, A. \& Zingales, L., 2004, 'Private benefits of control: An international comparison', Journal of Finance 59(2), 537-600. https://doi.org/10.1111/j.1540-6261.2004. 00642.x

Ernst \& Young, Fall 2002, Ernst \& Young's global corporate venture capital report for 2002 [online], viewed August 2009, from http//:www.ey.com

Frank, D.H. \& Obloj, T., 2014, 'Firm-specific human capital, organizational incentives, and agency costs: Evidence from retail banking', Strategic Management Journal 35(9), 1279-1301. https://doi.org/10.1002/smj.2148

Gaba, V. \& Bhattachary, S., 2012, 'Aspirations, innovation, and corporate venture capital: A behavioral perspective', Strategic Entrepreneurship Journal 6(2), 178199. https://doi.org/10.1002/sej.1133

Gimmon, E. \& Levie, J., 2010, 'Founder's human capital, external investment, and the survival of new high-technology ventures', Research Policy 39(9), 1214-1226. survival of new high-technology ventures',
https://doi.org/10.1016/j.respol.2010.05.017

Grossman, S.J. \& Hart, O.D., 1986, 'The costs and benefits of ownership: A theory of vertical and lateral integration', Journal of Political Economy 94(4), 691-719. https://doi.org/10.1086/261404

Grossman, S.J. \& Hart, O.D., 1988, 'One share-one vote, and the market for corporate control', Journal of Financial Economics 20(1), 175-202. https://doi.org/ 10.1016/0304-405X(88)90044-X

Hart, O.D. \& Moore, J., 1990, 'Property rights and the nature of the firm', Journal of Political Economy 98(6), 1119-1158. https://doi.org/10.1086/261729

Hart, O.D. \& Moore, J., 1994, 'A theory of debt based on the inalienability of human capital', The Quarterly Journal of Economics 109(4), 841-879. https://doi.org/ 10.2307/2118350

Hatch, N.W. \& Dyer, J.H., 2004, 'Human capital and learning as a source of sustainable competitive advantage', Strategic Management Journal 25(12), 1155-1178. https://doi.org/10.1002/smj.421

Helwege, J. \& Packer, F., 2009, 'Private matters', Journal of Financial Intermediation 18(3), 362-383. https://doi.org/10.1016/j.jfi.2008.12.001

Hitt, M.A., Bierman, L., Shimizu, K. \& Kochhar, R., 2001, 'Direct and moderating effects of human capital on strategy and performance in professional service firms: resource-based perspective', Academy of Management Journal 44(1), 13-28.

Ivanov, V., Krishnan, C.N.V., Masulis, R.W. \& Singh, A.J., 2011, 'Venture capital reputation, post-IPO performance and corporate governance', Journal of Financial and Quantitative Analysis 46(5), 1295-1333. https://doi.org/10.1017/ S0022109011000251

Jardon, C.M. \& Martos, M.S., 2012, 'Intellectual capital as competitive advantage in emerging clusters in Latin America', Journal of Intellectual Capital 13(4), 462-481. https://doi.org/10.1108/14691931211276098

Jørgensen, S., Kort, P.M. \& Dockner, E.J., 2006, 'Venture capital financed investments in intellectual capital', Journal of Economic Dynamics and Control 30(11), 2339-2361. https://doi.org/10.1016/j.jedc.2005.07.005

Kaplan, S. \& Stromberg, P., 2004, 'Characteristics, contracts, and actions: Evidence from venture capitalist analyses', The Journal of Finance 59(5), 2177-2210. from venture capitalist analyses', The Journal of
https://doi.org/10.1111/j.1540-6261.2004.00696.x

Lepak, D.P. \& Snell, S.A., 2002, 'Examining the human resource architecture: The relationships among human capital, employment, and human resource configurations', Journal of Management 28(4), 517-543. https://doi.org/10.1177/ configurations', Journa
014920630202800403

Lerner, J. \& Merges, R.P., 1998, 'The control of technology alliances: An empirical analysis of the biotechnology industry', The Journal of Industrial Economics 46(2), 125-156. https://doi.org/10.1111/1467-6451.00066

Likert, R., 1932, 'A technique for the measurement of attitudes', Archives of Psychology 22(140), 1-55

Lim, K. \& Cu, B., 2012, 'The effects of social networks and contractual characteristics on the relationship between venture capitalists and entrepreneurs', Asia Pacific Journa of Management 29(3), 573-596. https://doi.org/10.1007/s10490-010-9212-x

Liu, H. \& Sun, Z., 2005, 'The economic explanation for the origin and the allocation of the ruling rights of accounting standards', Accounting Research 218(12), 3-8.
Liu, X. \& Ma, H.J., 2004, 'Control rights allocation in R\&D alliance: Research of China's pharmaceutical', The Journal of Quantitative \& Technical Economics 21(6), 28-38.

Masulis, R.W. \& Nahata, R., 2009, 'Financial contracting with strategic investors: Evidence from corporate venture capital backed IPOs', Journal of Financial Intermediation 18(4), 599-631. https://doi.org/10.1016/j.jfi.2009.06.001

Medina, C.C., Cabrales, A.L. \& Cabrera, R.V., 2011, 'Leveraging the innovative performance of human capital through HRM and social capital in Spanish firms', The International Journal of Human Resource Management 22(4), 807-828. https://doi.org/10.1080/09585192.2011.555125

Mumcu, A., 2010, 'Strategic withholding of firm-specific skills in wage bargaining' Scottish Journal of Political Economy 57(2), 187-211. https://doi.org/10.1111/ j.1467-9485.2010.00513.x

Patzelt, H., 2010, 'CEO Human capital, top management teams, the acquisition of venture capital in new technology ventures: An empirical analysis', Journal of Engineering and Technology Management 27(3/4), 131-147. https://doi. org/10.1016/j.jengtecman.2010.06.001

Rajan, R.G., 2012, 'Presidential address: The corporation in finance', The Journal of Finance 67(4), 1173-1217. https://doi.org/10.1111/j.1540-6261.2012.01745.x

Ruzzier, M., Antoncic, B., Hisrich, R.D. \& Konecnik, M., 2007, 'Human capital and SME internationalization: A structural equation modeling study', Canadian Journal of Administrative Sciences 24(1), 15-29. https://doi.org/10.1002/cjas.3

Schmidt, K.M., 2003, 'Convertible securities and venture capital finance', The Journal of Finance 58(3), 1139-1166. https://doi.org/10.1111/1540-6261.00561

Shleifer, A. \& Vishny, R.W., 1986, 'Large shareholders and corporate control', Journal of Political Economy 94(3), 461-488. https://doi.org/10.1086/261385

Shleifer, A. \& Vishny, R.W., 1997, 'A survey of corporate governance', Journal of Finance 52(2), 737-783. https://doi.org/10.1111/j.1540-6261.1997.tb04820.x

Tan, J. \& Litschert, R.J., 1994, 'Environment-strategy relationship and its performance implications: An empirical study of Chinese electronic industry', Strategic Management Journal 15(1), 1-20. https://doi.org/10.1002/smj.4250150102

Tirole, J., 2001, 'Corporate governance', Econometrics 69(1), 1-35. https://doi.org/ 10.1111/1468-0262.00177

Turcan, R.V., 2008, 'Entrepreneur-venture capitalist relationships: Mitigating postinvestment dyadic tensions', Venture Capital 10(3), 281-304. https://doi.org/ investment dyadic tensions',
$10.1080 / 13691060802151960$

Vos, A.D. \& Dries, N., 2013, 'Applying a talent management lens to career management: The role of human capital composition and continuity', The International Journal of Human Resource Management 24(9), 1816-1831. https://doi.org/10.1080/095 85192.2013.777537

Wang, H.Z., Wuebker, R., Han, S. \& Ensley, M., 2012, 'Strategic alliances by venture capital backed firms: An empirical examination', Small Business Economics 38(2), 179-196. https://doi.org/10.1007/s11187-009-9247-x

Wang, L., 2014, 'Specific investment, trust and control rights governance in venture capital-backed entrepreneurial firms', Journal of Management Science 27(5), 50-68.

Wang, L. \& Dang, X.H., 2008, 'Residual rights of control residual rights of claim and growth performances of corporation: An empirical study on governance structure of state-owned listed companies in China based on theory of incomplete contract', China Soft Science 8, 128-138.

Weber, C. \& Weber, B., 2005, 'Corporate venture capital organization in Germany', Venture Capital 7(1), 51-73. https://doi.org/10.1080/1369106042000316350

Williamson, O.E., 1996, 'Transaction cost economics and the Carnegie connection', Journal of Economic Behavior \& Organization 31(2), 149-155. https://doi. org/10.1016/S0167-2681(96)00898-0

Yang, R.L. \& Yang, Q.J., 2001, 'Specificity, exclusiveness and enterprise institution', Economic Research Journal 36(3), 3-12.

Yang, R.L. \& Zhou, Y.A., 1997, 'A normal analysis frame for the arrangement of property rights of enterprises: A supplementary comment on Zhang, Zhou \& Cui's opinions', Economic Research Journal 32(1), 12-22.

Zhang, Z.H., Jia, M. \& Wan, D.F., 2009, 'Allocation of control rights and cooperation efficiency in public-private partnerships: Theory and evidence from the Chinese pharmaceutical industry', International Journal of Health Care Finance \& Economics 9(2), 169-182. https://doi.org/10.1007/s10754-009-9063-5

Zhou, R.J. \& Gao, K.J., 2012, 'The effect of large shareholder's control on managers' ownership incentive', Accounting Research 295(5), 50-59.

Zhou, Y.A., 2002, 'Human capital, uncertainty and governance of high-new technology firms', China Industrial Economy 175(10), 52-59. 